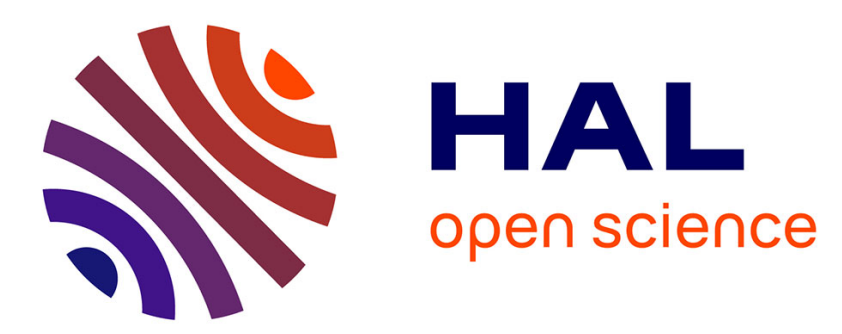

\title{
Microfinance development in Armenia: Sectoral characteristics and problems
}

Knar Khachatryan, Emma Avetisyan

\section{To cite this version:}

Knar Khachatryan, Emma Avetisyan. Microfinance development in Armenia: Sectoral characteristics and problems. Strategic Change, 2017, 26 (6), pp.575 - 584. 10.1002/jsc.2169 . hal-01695638

\section{HAL Id: hal-01695638 \\ https://hal-audencia.archives-ouvertes.fr/hal-01695638}

Submitted on 29 Jan 2018

HAL is a multi-disciplinary open access archive for the deposit and dissemination of scientific research documents, whether they are published or not. The documents may come from teaching and research institutions in France or abroad, or from public or private research centers.
L'archive ouverte pluridisciplinaire HAL, est destinée au dépôt et à la diffusion de documents scientifiques de niveau recherche, publiés ou non, émanant des établissements d'enseignement et de recherche français ou étrangers, des laboratoires publics ou privés. 


\title{
The development of microfinance in Armenia: sectoral
}

\author{
characteristics and problems
}

\section{The development of microfinance in Armenia}

The heavy-handed regulation enforced a commercialization process and as a result pushed microfinance institutions towards a commercial logic. This commercial shift, in its turn, diminished the importance of the social component.

\author{
Knar Khachatryan \\ College of Business and Economics, American University of Armenia \\ and KTO SKEMA Business School \\ 40, Baghramyan Avenue, 0019 Yerevan, Armenia \\ E-mail: kkhachatryan@aua.am \\ Tel: 00374 (10) 612568
}

\author{
Emma Avetisyan* \\ Audencia Business School \\ 8 Route de la Jonelière \\ 44312 Nantes Cedex 3, France \\ E-mail: eavetisyan@audencia.com \\ Tel: 0033 (0)2 40378119
}

*Corresponding author 


\section{Key Points}

1. The main objective of microfinance in Armenia was to address increasing unemployment and the poverty resulting from transitional shock.

2. The development of the microfinance sector as a complementary mechanism to conventional financial intermediation is considered highly beneficial.

3. Our findings allowed classifying main problems into unfair fees, limit on annual interest rate, late cooperation between credit organizations, and regulated microfinance operations.

JEL classification codes : G21, G28, G34

\section{Author Biography}

Emma Avetisyan is Associate Professor at the Business and Society department of Audencia Business School. Her research in the field of CSR focuses on the emergence and evolution of CSR rating agencies and their role in the standardization and institutionalization of CSR in the financial marketplace and corporations.

Knar Khachatryan is Assistant Professor of Marketing and Management at the American University of Armenia (AUA)'s College of Business and Economics and affiliated researcher at KTO, SKEMA Business School. Her research in microfinance concentrates on incentive mechanisms to address contract enforcement and screening problems. 


\section{INTRODUCTION}

Changes are taking place in the field of finance for low-income people: the objective is to mitigate poverty and develop their income-generating activities. Indeed microfinance is questioned as a poverty-alleviation tool (Biosca et al., 2014), devised in an innovative and sustainable way (Milana and Ashta, 2012) that has emerged to fill the gap left by larger, conventional financial intermediaries. The main objective of microfinance is to serve the population facing the highest financial risks and those who are either unbanked or considered unbankable.

In the academic literature microfinance institutions (MFIs) are often considered hybrid organizations since they fulfil a 'double bottom line' mission by pursuing both social and financial objectives (Haigh and Hoffman, 2014; Ashta and Hudon, 2012; Battilana and Dorado, 2010; Dacin et al., 2010; Agier and Szafarz, 2013).

Microfinance has different configurations depending on the type of country: wealthy or poor (Milana and Ashta, 2012). Therefore, it is often necessary to adjust microfinance practice to the technical, socio-cultural and political features of the new context in order to facilitate its adoption and subsequent diffusion (Akrich et al., 2002; Ansari et al., 2010; Latour, 1986).

As an intervention and poverty alleviation tool supporting economic development, microfinance grew rapidly in the region of Eastern Europe and Central Asia (ECA) around the 1990s. During that period, international organizations and networks (for example SEF/VFI/World Vision, OXFAM, Save the Children, International Project Consulting, UMCOR, Eclof, FINCA) and religious charities (for example Catholic Relief Services) initiated various microfinance activities in this region.

We narrowed down our study to a particular country within the ECA region: our 
objective is to shed light on the characteristics of microfinance in Armenia. Studying the specificities of microfinance development in Armenia is interesting for at least two reasons. First, the evolution of the financial and regulatory systems has intensified competition between commercial banks and MFIs with regard to serving the marginalized urban and rural population, as well as start-ups. In the face of a highly regulated market, specialized microfinance service providers were compelled to transform. Second, the ongoing global commercialization of microfinance drove commercial banks to become closer to, and more accessible for villagers, poor households and micro-entrepreneurs. They achieved this not only by adjusting their products to meet the financial needs of these clients but also by providing them with non-financial services, which seek to enhance the poverty-alleviation impact of the financial services provided by the institution and to protect microfinance clients (Biosca et al., 2014).

In the light of the above-mentioned developments and the dual (economic and social) mission of microfinance, it is interesting to explore the development and characteristics of microfinance in Armenia. Therefore, we formulated our research question as follows: What are the characteristics - definition, lending practices, actors involved and problems encountered - of microfinance in Armenia?

Given that our main research interest lies in exploring the characteristics of the microfinance sector in Armenia and identifying the problems it faces, we adopted a multi-case study research design (Eisenhardt, 1989; Yin, 2003). Relying on evidence from multiple cases allows for data triangulation, a process that enhances the validity and robustness of qualitative analyses (Yin, 2003). 
The cases have been sampled to include microfinance service providers in Armenia that are listed in the Microfinance Information Exchange (MIX) Market database (see Table 1). Out of fifteen microfinance service providers on the Mix Market list, we interviewed twelve; these are organizations with diverse development paths and approaches to traditional microfinance practice. We hold that various 'unbanked' and 'unbankable' population segments, to whom their products are addressed, as well as the origins of these institutions, have give birth to different characteristics.

Interview was chosen as our primary source of data and the preferred means for gathering information, because it allows greater access to individual strategies and leads to the disclosure of complicated, sensitive and firm-specific information thanks to the interviewer's personal touch. We interviewed founders, board members, CEOs and other top management representatives of microfinance service providers, but also held informal discussions with field experts, including the former Prime Minister of the Republic of Armenia (Hrant Bagratyan). All the interviews (except one) were run faceto-face and, on average, lasted 60-90 minutes. We complemented and double-checked our first-hand information with various secondary sources including newspapers, publications, existing surveys, and studies, which we mention later in the paper. Our data analysis followed approaches commonly used in qualitative research studies (Miles and Huberman, 1984; Eisenhardt, 1989; Yin, 2003).

\section{MFI DEVELOPMENT IN ARMENIA}

In this part we will present the development of the microfinance sector in Armenia. A close reading of academic articles, domestic reports and publications by the 
Central Bank of Armenia (CBA), the National Statistical Service of the Republic of Armenia, the Ministry of Finance and Economy of the Republic of Armenia, as well as publications by international organisations (World Bank, Microfinance Centre, Microbanking Bulletins, Mix Market, Planet Finance, International Monetary Fund, Heritage Foundation) - served as the material we needed to describe the development of this sector. We divided the period surveyed (1991 to present day) into three phases.

The first phase corresponds to the emergence of the microfinance sector through the active participation of well-known international organizations (for example FINCA, Oxfam, Umcor, SEF/VFI/World Vision) and religious charities (for example Catholic Relief Services). In the section on the first phase, we will also highlight the country's economic and financial situation, which explains the demand for a poverty alleviation and financial inclusion tool. The second phase corresponds to the internal transformation of the sector, with the introduction of the Law on Credit Organizations by the CBA, which drove the MFI sector to commercialize and move closer to banks. In the section concerning the final phase, we will describe the current situation of the sector and outline some signs of sector consolidation. Figure 1 gives an overview of the three phases and outlines the evolution pattern of microfinance in Armenia.

\section{Phase 1: 1991-2001 - Microfinance as a Post-independence Poverty Alleviation}

\section{Tool}

In the early 1990s Armenia's economy was in an unfavourable condition caused by several significant events: the devastating earthquake of 1988 , the collapse of the Soviet Union in 1991, continuing conflicts with, and blockade by two neighbouring countries (Azerbaijan and Turkey) and so on. 
After independence was declared in 1991, the government undertook a wide range of structural reforms, such as: privatisation of land and state-owned enterprises, liberalization of prices, and other reforms in tax administration and the financial sector; these were designed to strengthen financial institutions and improve governance.

The collapsing economy led to hyperinflation, a large budget deficit (that peaked at 55 per cent of GDP in 1993), factory closures, a deficient electricity supply and mass emigration. As a consequence, poverty mushroomed to about 56 per cent of the population around 1998/1999 (IDA 2007). Other challenges included a low per capita income, a large informal sector, unemployment increasing from 8.9 per cent in 1998 to 10.3 per cent in 2001 (CBA 1998, 2001), a low level of financial intermediation and the economy's heavy dependence on the dollar.

In order to support the country's economic development several international financial institutions offered their assistance. The International Monetary Fund (IMF), World Bank, European Bank for Reconstruction and Development (EBRD), as well as other international financial institutions, extended considerable financial and technical assistance to the government of Armenia. Also, in order to deal with the large-scale banking crisis (partially due to the failure of several commercial banks), the CBA adopted a series of measures whose objective was to strengthen banking sector supervision, encourage privatization and consolidation, raise mandatory requirements for deposits and impose penalties for non-compliance.

Thus, the first initiatives in the microfinance sector can be traced back to around the mid-1990s, when a number of international organizations, networks and charities (among which SEF/VFI/World Vision, OXFAM, Save the Children, UMCOR, Eclof and FINCA) supported the emergence of microfinance activities - their objective being 
to address increasing unemployment and the poverty resulting from transitional shock. As a complementary effort in filling the gap in the financial services industry, microfinance provided an opportunity for entrepreneurial people who, under communist rule, had only been allowed to run very small 'craft' or agribusinesses. Under the new market realities, they had the opportunity to expand their operations and deploy their potential (Pytkowska and Rataj, 2006).

\section{INSERT TABLE 1 ABOUT HERE}

The majority of microfinance service providers in Armenia followed the typical MFI development path observed across the world: they started either as local offices of donor organizations or as projects carried out by donor organizations (Battilana and Dorado, 2010; Hudon and Traca, 2011).

\section{Phase 2: 2002-2013 - Regulation and Institutional Transformation}

Notwithstanding important reforms made over the past few years, financial sector development in Armenia has lagged behind other transition countries. A deepening of financial intermediation has been hindered by high cash ratios, credit risk, lack of competition and institutional weaknesses. Armenia has a large shadow economy, which further limits the scope for financial intermediation (IMF, 2006).

In 2002, the Armenian government created National Council of Sustainable Development headed by the Prime Minister and supported by the World Bank. Within the framework of the National Strategy for Sustainable Development the government of Armenia harmonized certain activities; this was meant to put sustainable development 
principles into practice, particularly in the economic sector, environmental protection, territorial administration as well as higher education. With regard to this, gradually microfinance service providers started offering 'thematic' loans (for example construction or renovation of energy-saving houses, education) and encouraged projects with social and environmental dimensions. However, fulfilling triple bottom line objectives, namely social, environmental and financial (Schuite and Pater, 2008), could not realistically be expected.

In the same year microfinance experienced a heavy structural transformation when the CBA enacted the Law on Credit Organizations (CBA, 2002). The law governed the licensing procedure, together with the regulation and supervision of the activities of credit organizations (COs), including credit unions, savings unions, leasing and factoring organisations and other credit organisations. It also set down the procedure for changing the type of activity of banks operating on the territory of the Republic of Armenia. According to this law 'all organizations involved in accepting deposits and/ or lending should be licensed either as a bank or as a credit organization; foundations are not an acceptable legal structure to obtain a license' (CBA, 2002).

Although the law was initially created for banks that failed to operate as such, it was immediately clear that microfinance crediting activity would fall under this law and that microfinance service providers were required to be licensed as credit organizations within six months of the law entering into force.

Many heads of microfinance organizations complained; they claimed that the regulation did not take into account the specificities of the sector and that microfinance had to be considered as a separate subfield for the sake of retaining its original mission. Thus almost all microfinance service providers were reluctant to place themselves under the 
prudential regulation of the CBA which, in 2005, introduced some amendments to simplify the MFIs' transformation requirements.

Even if microfinance activities were now regulated by law, which brought in some clarity, incumbent players found themselves in a completely unexplored world of business relationships, reporting and standards with which they had to comply. Consequently, the law led to mission drift and commercialization for the majority of MFIs. As a result the social component decreased and MFIs found themselves in the situation where one of the double bottom line logics - financial - could become dominant (Kraatz and Block, 2008).

During this phase poverty remained a critical issue, particularly in rural areas and among socially vulnerable groups. Although the IMF Poverty Reduction and Growth Facility supported programmes to reduce poverty rates from 56 per cent in 1998/1999 to around 28 per cent in 2005 (IMF, 2007 Country Report No. 07/377, 4), the government was not able to maintain this decrease and poverty rates increased again after the global financial crisis of 2008 .

In the ECA region as a whole, the weakened global financial environment and unfavourable macroeconomic conditions have created serious preoccupations for microfinance practitioners and regulatory bodies. In particular, according to a joint report by the Microfinance Information Exchange (MIX) and Consultative Group to Assist the Poor (CGAP) (2011), the financial crisis of 2008 hit MFIs in the ECA region harder than anywhere else in the world. Consequently, MFIs in the ECA had the lowest profitability indicators worldwide and the worst portfolio quality since the inception of the sector. 
According to the World Bank's recent indicators concerning poverty rates at national poverty lines, 32 per cent of the country's population lived below the national poverty line in 2012 against 35 per cent in 2011 (World Bank, 2014). In the same period, unemployment increased sharply from 6.2 per cent in 2011 to 17.3 per cent in 2012 (CBA, 2011; 2012). Finally, as stated in the 'Social Snapshot and Poverty in Armenia' report in 2012 the total (upper, lower and the extreme) poverty lines per adult equivalent per month were estimated to be AMD 37044 (or USD 92.2), AMD 30547 (or USD 76.0) and AMD 21732 (or USD 54.1), respectively.

All the above-mentioned facts provided a strong basis for continued interest in microfinance services. Table 2 summarises the gross loan portfolio of the MFIs under study for this period.

INSERT TABLE 2 ABOUT HERE

Phase 3: 2014-present - Consolidation of Microfinance Service Provider Organizations

Since 2014, microfinance service providers have been looking for relevant peers for the purpose of consolidation and to discuss opportunities to join forces with other local players in the market.

INSERT FIGURE 1 ABOUT HERE

The sector saw a first consolidation wave when Global Credit acquired GFC General 
Financial and merged with Washington Capital. The objective reason for this consolidation, from Global Credit's standpoint, was to achieve synergies between some products. Washington Capital strengthened the mortgage loan portfolio in rural zones and GFC brought competencies from the agricultural loan market. Another CO (credit organization), Good Credit, is currently in the process of being acquired by an EUbased MFI. Likewise, there are ongoing negotiations about a future merger between FINCA and Aregak.

The main reason for this consolidation is market oversaturation, with currently 24 commercial banks and 33 COs. The majority of those commercial banks and COs provide various microfinance products and services, even if the latter are not always called microfinance products. The existence of numerous players is not optimal for such a small economy: it makes the market less effective and supervision more difficult. Therefore the ongoing consolidation will help incumbent players to increase their scale of operation, their portfolio of products and the number of their customers, and achieve some synergy effects. It will also strengthen their ability to deal with market fluctuations and various challenges.

\section{CHARACTERISTICS OF MICROFINANCE IN ARMENIA}

What is Microfinance in Armenia? Almost all definitions of microfinance refer to the concept of small loans given to borrowers at the bottom of the pyramid who otherwise have no access to conventional banking services. The notion of 'poor' often implies illiterate persons with limited collateral, no official credit history and who are dispersed across a rural geography (Khavul, 2010). In microfinance, terms often considered universal such as 'loan', 'repayment', 'interest rate', in fact take on a variety of local 
meanings; this can lead to intractable misunderstandings and the misuse of microcredit programmes (Guérin et al., 2013; Shipton, 2010).

'The majority of our clients have about up to 2,000,000 AMD loans. If we have 56000 clients, 46000-48000 of those clients have a maximum of 2,000,000 AMD loans. Can you talk about microfinance in this case? ... [...]... Can you talk about microfinance if ProCredit gives no less than USD 10000 loan? The majority of our clients do not have a choice as they cannot take a loan elsewhere.' (FINCA, interview)

In this context, regulation is considered as the place where the dominant vision of what microfinance should be is defined (Halouani and Boujelbène, 2015). In the absence of a formal definition of microfinance (its target groups, amount of loans, duration of credit repayment, etc.), the meaning of 'poor' and 'small loan' is quite specific in Armenia.

'In our country there is no microfinance concept. We do not have a definition of microfinance. We were negotiating a lot with the CBA to give us a definition and to explain which loans are considered to qualify as microfinance loans. For example, AMD 7million can also be micro if we talk about big economy. So, each organization has defined itself what microlending is for it and follows its own policy. We acquired GFC and when we look at them - microfinance lending is between AMD 200,000-800,000. Even if the market is very saturated there is a lot of work to be done.' (Global Credit, interview)

Lending Practices. Over a long period, scholarly interest has focused largely on group lending models (Varian, 1990; Morduch, 1999) pioneered by Grameen Bank in Bangladesh and BancoSol in Bolivia. At the moment, there is a clear growing trend for employing individual lending contracts, in particular in transition economies (Bhole and Ogden, 2010; Tedeschi, 2006; Egli, 2004).

The microfinance sector in Armenia is also distinctive as regards its approach to group lending and individual lending practices. The results of the surveys and internal observations done by the MFIs under study confirmed that in many cases villagers were artificially creating groups because there was no possibility to get an individual loan. 
There was a need to address client needs better through a customer-centred approach (Milana and Ashta, 2012) and a shift from group loans to individual loans (through guarantees or collateral) was considered necessary.

In this regard, Nor Horizon initially provided group lending based on Indian self-help groups, with the objective to help urban businesses. This was based on the following rationale: large groups were made up of sub-groups and each sub-group had to repay its loans so that the next sub-group could take out a loan based on performance. In 2007 Nor Horizon ended group lending because it did not serve its real mission and was abused.

Likewise, ACBA was giving group loans to a Union of Villagers (created on the French Credit Agricole model), which distributed the amount among its 50 members. Nowadays it gives more individual loans to farmers who are not members of the Union of Villagers. Inspired by American Farm Credit, Farm Credit Armenia has also specialized in individual agro-loans. The only visible proponents of group loans are Kamurj and Aregak, which use the solidarity group lending approach in the Save the Children model.

Empowerment of Women. According to the MIX and CGAP reports of 2011, genderoriented goals are not prominent among ECA MFIs, which serve only a small proportion of women clients (42 per cent) compared to other regions.

Although the evidence to date is not conclusive about the impact of microcredit on women's empowerment (Pal and Dutta, 2015), our findings suggest that even if local MFIs systematically make efforts to empower women by offering them credit opportunities, it is difficult to work out why the number of women in the client portfolio 
is lower than expected. Some international organizations (for example Eclof) require the credit portfolio to include 50 per cent of women borrowers and other local organizations (for example Kamurj and Aregak) deliberately targeted women at the beginning of their activity; nonetheless the proportion of women borrowers is much lower than the proportion of men taking out loans (especially in rural areas).

This situation is puzzling given the fact that the majority of men in villages spend about half of the year working in Russia. Women stay in Armenia to take care of businesses and run the farms. From the standpoint of poverty alleviation, they are also more likely to want to invest in the education and health of their children and therefore are less likely to risk being excluded from future loans through defaulting (Armendariz and Morduch, 2005).

In 2004, SEF took the first steps in understanding and contextualising the reasons for not being able to have more than 33 per cent of women in their client portfolio:

'We understood that there are a lot of cases when women are doing the business but it is the men who are coming and taking the loan and signing the paper. Why? We put quite strong requirements on our credit officers to find out the real beneficiary, the real 'businessman' behind this business. If this was the female we could realize it very quickly, because he [the husband] could not answer the concrete questions on income, expenses and turnover. So, we turned our portfolio from not knowing our women clients to knowing them. ...[...]...We now have about 51 per cent of female clients. We do not push this figure artificially up but we try to find out those cases.' (SEF, interview)

Market Overlap and Commercialization. In the mid-1990s, when microfinance started to develop in Armenia, there was a choice between establishment on a commercial (for example SEF) or non-commercial basis (for example Horizon, ECLOF, FINCA, Kamurj). Throughout the evolution of the sector, MFIs globally, and particularly in Armenia, discovered that development aid and subsidized credit were not sufficient to cover demand. In this respect, the commercialization process implied opening up the 
microfinance industry to the application of market-based principles, and moving from donor-dependent and subsidised operations to commercial debt financing (Christen and Drake 2002, 4). This type of financing usually requires new capital from outside investors and regulatory approval by local banking authorities, but also improved governance and internal controls (Armendàriz and Morduch, 2010). In the case of Armenia, local regulation contributed to the commercialization process - especially through the introduction of the law on COs.

This law and its further amendments constantly increased the minimum capital required from COs by forcing them either to join forces or search for foreign investments. Even if it has been claimed that this process had some positive impact, it also led to a drift away from the original social mission (Xu et al., 2015, Ledgerwood and White, 2006: xxxii; Eikenberry and Kluver, 2004; Kent and Dacin, 2013).

Meanwhile, commercial banks in Armenia have actively started a downscaling strategy: the market segment of large corporations was becoming saturated and they could see opportunities in providing loans both to SMEs and individuals. Although the number of products targeting low and medium-level income-earners was constantly increasing, the majority of banks were reluctant to use the word microfinance, wishing not to be perceived as a microfinance institution. Until now only three banks (namely ProCredit, ACBA and Inecobank) have reported to the Mix Market platform as a microfinance service provider.

In a situation where markets overlap, COs need to be more competitive in the field of non-monetary issues (flexibility, product diversity, client relationships) since competition on the price side is not possible. On the one hand, banks benefit from regulation, crowdfunding and $\mathrm{CBA}$ lobbying, thus they have more opportunities to 
bring in cheaper funds from the outside as well as from inside. On the other hand, regulation does not allow COs to collect savings and deposits from clients, thus they need to look for external investments:

'Banks have entered our competitive field, which makes our life difficult. There is a growing competition, which made incumbent firms more sophisticated. On the other side our clients demand more complex services, which are more bank services. So, we either have to leave our clients to go to banks or try to solve the problems for them. The competition has increased and we have probably reached a higher stage of institutional development. ...[...]... In Syunik region, in 2011, we were the only organization that was giving mortgage loans. Then, banks entered and took the market from us as we did not have the competitive rate.' (SEF, interview)

\section{PROBLEMS}

Unfair Fees. One important difference between banks and COs lies in the amount of mandatory fees for each branch. Compared to banks, which only need to make a lump sum payment of AMD 250000 when they open a branch, COs have to pay the same amount for their branches annually. This obviously makes it difficult to compete both for large COs - such as Aregak and FINCA, with about 40 and 30 branches, respectively - but also for small players that see regional opportunities for growth. One method used to avoid branch fees is the practice of branchless banking:

'This is affecting us, as we have 31 branches, so we speak about USD 15000 per year. Beside the fact that it makes MFIs, which have many branches less, competitive it is also giving advantage to banks offering microfinance services, which do not pay these fees. ...[...]... The banks were paying before, but the regulation changed for them.' (FINCA, interview)

A similar situation has arisen as regards the fees for work with the Financial System Ombudsman, where banks pay 0.01 per cent of their assets, whereas COs pay 0.07 per cent. As a result, some COs pay almost as much as commercial banks, yet, in terms of 
assets, COs are much smaller.

Finally, COs can buy and sell foreign exchange currency only through banks. Due to the fact that most of the COs incorporate investments in foreign currency (mostly in dollars) and consumer loans are given only in Armenian drams, COs depend heavily on banks to change their currency. This makes COs such as FINCA vulnerable; this CO buys and sells around 50 million dollars every year, and its loans are generally not below AMD 2 million.

Limit on Annual Interest Rate. Another problem is the cap on interest rates in the Civil Code, which does not allow COs to give micro-loans with an interest rate higher than double the banking rate, as stated by the CBA (12 per cent as of 2015). This interest rate cap requirement puts a strong pressure on COs: they have to lend with an annual interest rate no higher than 24 per cent, which often does not even cover the costs of lending. As a consequence many microcredit lenders artificially charge other fees, such as a frontoffice fee, consulting, or a monthly fee, to ensure sufficient revenue. The management of this pricing policy is labour-intensive and time-consuming, therefore costly. Besides, most of the incorporated external funds are in dollars and there is a need to hedge the foreign currency risk since the loans are mostly given in AMD (under the law on consumer loans these can only be given in AMD).

Belated Cooperation Between Credit Organizations. As stated by MicroFinanza Rating, Armenian microfinance is 'quite loose and lacks internal coordination and transparency'. Moreover, the Micro Enterprise Development Initiative, which was created and funded by USAID to support Armenian microfinance and institutions, came 
to an end in late 2006. Then the most active COs initiated the Union of Credit Organizations of the Republic of Armenia (UCORA), which was active for more than a decade.

In 2007, during the initial stage of UCORA's formation, members received an invitation from the Union of Armenian Banks (UAB) to enter this already existing organization and defend the interests of COs within the framework of UAB. In his interview / with Mediamax Agency and Banks.am portal, Khoren Kerboyan, the Chairman of UCORA stated: 'During further discussions, we came to a conclusion that the role of COs in UAB would be somewhat secondary. Besides, there was that conflict of interests, since we are competing organizations in the market of crediting'. Hence, to avoid being 'lost' within the UAB, at least because the name itself did not mention credit organizations, a decision was taken to create an independent structure and cooperate with the UAB productively and, possibly, reach agreement upon a common position on a number of issues.

In 2010, six (founding) members of UCORA (namely Aregak, FINCA, Farm Credit Armenia, SEF International, New Horizon and GFC) covered about 40-45 per cent of the market of COs, both in terms of the number of customers and the volume of the credit portfolio and assets. By that time four more COs had shown interest in joining UCORA. In 2010 UCORA received a EUR 62500 grant from Dutch 'Oxfam-Novib', which helped to solve the problem of paying for premises, to purchase the necessary stock and equipment, and to pay salaries to the UCORA staff.

By the end of 2014, UCORA had increased the number of its member organizations, reaching 12 out of 33 players in the market, as compared to 6 members (out of 28) in 2010. A more active participation of field members and more initiatives are now needed 
to contribute to the further development of microfinance activities.

Regulated Microfinance Operations. According to the Law on Credit Organizations, microlending is considered a solely 'commercial' activity, that is to say its purpose is to grant loans to (individual) entrepreneurs or legal entities. However, one of the principles of microfinance is also to give loans to individuals whose business is not registered. About 65 per cent of Nor HORIZON's portfolio is composed of consumer loans, out of which 80-90 per cent is given to people whose business has not been registered yet. Currently the pressure exercised by the CBA regulations inhibits the economic and social development of MFIs (Hartarska, 2005) and leads to a deviation from the original social mission: in many cases the mortgages of microfinance clients are used as collateral.

\section{CONCLUSION}

After the fall of communism a culture of financial intermediation began to take off in many ECA countries. Armenia is a developing economy; hence poverty alleviation, employment creation and social inclusion are among the most important priorities of the government. In this light, the development of the microfinance sector as a complementary mechanism to conventional financial intermediation is considered highly beneficial. This will allow the untracked population to be reached and enable the creation of customer-centred services based on existing demand and adjusted to clients' changing needs. In this connection, a clear move has already taken place: from group lending to individual lending, because market surveys and clients' feedback showed that group lending was not an efficient approach in the Armenian context. Also efforts have 
been made to understand the reasons for the low proportion of women among credit borrowers.

\section{Hardly Keeping the Dual Promise}

While regulation and supervision serve as an external governance and control mechanism for many MFIs (Hartarska, 2005), our findings suggest that in the case of Armenia heavy-handed regulation enforced a commercialization process and as a result pushed MFIs towards a commercial logic. This commercial shift, in its turn, diminished the importance of the social component. Clearly this reflects the ongoing debate among key institutional players, who disagree about whether or not earning profits is a legitimate goal for a microfinance institution (Pache and Santos, 2010). Moreover, in a situation of unfair competition, where COs offer uncompetitive loan rates (compared to commercial banks), have limited access to international funds and are not allowed to provide more services for their clients, the transformation and consolidation of MFIs may be necessary for the sake of ensuring a sustainable business model.

On the social side, out of all the MFIs under study, only FINCA, Kamurj, Aregak, SEF and Nor Horizon claim that they focus on their social mission and continually integrate social features into every product design. In this regard, SEF prefers working with annuity payments to improve the financial discipline of borrowers, applies no penalty for early repayment and rejects the practice of bullet loans. FINCA is well known for its social projects and claims to be the only $\mathrm{CO}$ providing free life insurance to its borrowers. Another player, Nor Horizon, refuses non-ethical lending projects promoting the development of tobacco, alcohol or other sin industries. In contrast, GoodCredit did 
not even follow the traditional path of MFI development - from NGO to commercial establishment - and was driven by private financial considerations from its inception. As for commercial banks microcredits are only a small part of their large portfolio and downscaling strategy. Therefore, social and environmental projects play a role in their overall CSR strategy rather than at the core of their missions.

We acknowledge that some other COs or commercial banks in Armenia also provide micro-loans, support several social and environmental projects and thereby unintentionally are part of the microfinance field. However they do not report to Mix Market and do not consider themselves microfinance players. In Armenia microfinance has obviously reached its stated goal: improving the financial inclusion and literacy of the 'unbankable' part of the population. Although it has helped low and middle-income people in urban zones who wished to start a small business or expand their activities, its influence is more visible in rural zones, where villagers did not have any access to conventional banks. Indeed some microfinance providers, such as ACBA or Farm Credit Armenia, were initially designed for commercial farmers and SME agribusinesses. Besides, before taking out loans farmers and villagers were offered several non-financial services such as training courses and seminars. Future borrowers even had dedicated online platforms at their disposal, enabling them to calculate the cost of credit and apply for a loan.

In order to reach their financial inclusion goal, some microfinance service providers refused cash transactions and 'forced' borrowers to open bank accounts, thereby opening the door to conventional banks for them. Notwithstanding this progress, borrowers' ability to repay on time and their creditworthiness has not improved considerably. In fact clients sometimes simply have no other means of repayment than 
taking another loan in another bank or CO. This raises the question of whether microfinance has been successful as a poverty alleviation tool in Armenia. We therefore encourage other researchers to explore the extent to which microfinance has improved borrowers' financial stability in Armenia and it's overall impact both short-and-longterm.

It is possible that because of the high interest rates and difficult economic situation, micro-loans do not necessarily help poor people in Armenia to escape poverty, but instead push them further down into greater poverty.

While recent literature has claimed that it is possible to combine triple line objectives, namely social, environmental and financial (Rippey, 2009; Van Elteren, 2007; Schuite and Pater, 2008), we think that in Armenia microfinance has hardly managed to keep its dual (social and financial) promise.

\section{REFERENCES}

Agier I, Szafarz A. 2013. Microfinance and Gender: Is There a Glass Ceiling on Loan Size? World Development 2013, 42:165-181.

Akrich M, Callon M, Latour B. 2002. The Key to Success in Innovation. International Journal of Innovation Management 2002, 6 (2): 187-206.

Ansari, S.M., Fiss P.C., and E.J. Zajac, 2010. Made to fit: how practices vary as they Diffuse. Academy of Management Review 2010, 35 (1): 67-92. 
Armendáriz B, Morduch J. 2005. The economics of microfinance. Cambridge, MA: The MIT Press.

Armendáriz B, Morduch J. 2010. The Economics of Microfinance ( $2^{\text {nd }}$ Eds.). Cambridge, MA: The MIT Press.

Ashta A, Hudon M. 2012. The Compartamos Microfinance IPO: Mission Conflicts in Hybrid Institutions with Diverse Shareholdeing. Strategic Change, 2012; 21: 331-341.

Battilana J, Dorado S. 2010. Building Sustainable Hybrid Organizations: The Case of Commercial Microfinance Organizations. Academy of management Journal 2010, 53 (6): 1419-1440.

Biosca O, Lenton P, Mosley P. 2014. Microfinance Non-Financial Services as a Competitive Advantage: The Mexican Case. Strategic Change 2015, 23(7-8) : 507-516

Bhole B, Ogden S. 2010. Group lending and individual lending with strategic default. Journal of Development Economics 2010, 91: 348-363.

Egli D. 2004. Progressive Lending as an Enforcement Mechanism in Microfinance Programs. Review of Development Economics 2004, 8 (4): 505-520.

Central Bank of Armenia. 2002. Law on Credit Organizations.

Central Bank of Armenia. 2012. Statistical Bulletin.

Central Bank of Armenia. 2011. Statistical Bulletin.

Central Bank of Armenia. 2001. Statistical Bulletin.

Central Bank of Armenia. 1998. Statistical Bulletin.

Christen R.P. Drake D. 2002. Commercialization. The new reality of microfinance. In The Commercialization of Microfinance. Balancing Business and Development, Armendáriz B and Labie M (eds.). Kumarian Press, Bloomfield; chapter 1, 2-22. 
Dacin P.A., Dacin M.T., Matear M. 2010. Social Entrepreneurship: why We Don't Need a New Theory and how we move forward from here. Academy of Management Perspectives 2010, 24 (3): 37-57.

Eikenberry A.M., Kluver J.D. 2004. The Marketization of the Nonprofit Sector: Civil Society at Risk? Public Administration Review 2004, 64 (2): 132-140.

Eisenhardt, K. 1989. Building theories from case study research. Academy of Management Review 1989, 14 (4): 532- 550.

Guérin I, Morvant-Roux S, Villarreal M. 2013. Microfinance, debt and over-indebtedness. Juggling with money. London: Routledge.

Haigh N, Hoffman A.J. 2014. The New Heretics Hybrid Organizations and the Challenges They Present to Corporate Sustainability. Organization and Environment 2014, 27(3): 223-241.

Halouani N, Boujelbène Y. 2015. External Governance and Dual Mission in the African MFIs. Strategic Change 2015, 24(3): 243-265.

Hudon M, Traca D. 2011. On the Efficiency Effects of Subsidies in Microfinance: An Empirical Inquiry. World Development 2011, 39 (6): 966-973.

International Development Agency. 2007. Armenia: Reaping the Benefits of Steady Reforms. International Monetary Fund. 2006. Republic of Armenia: Poverty Reduction Strategy Paper. Progress Report. Country Report No. 06/239.

Kent D, Dacin M.T. 2013. Bankers at the gate: Microfinance and the high cost of borrowed logics. Journal of Business Venturing 2013, 28(6): 759-773.

Khavul S. 2010. Microfinance: Creating opportunities for the poor?. The Academy of Management Perspectives 2010, 24 (3): 58-72. 
Kraatz M.S. Block E.S. 2008. Organizational Implications of Institutional Pluralism. In Sage Handbook of Organizational Institutionalism, Greenwood R et al. (eds.). SAGE Publications Ltd.

Kwon J.W. 2010. An Analysis of Organisational, Market and Socio-cultural Factors Affecting the Supply of Insurance and Other Financial Services by Microfinance Institutions in Developing Economies. The Geneva Papers on Risk and Insurance-Issues and Practice 2010, 35 (1): 130-160.

Latour B. 1986. The Powers of Association. Power, Action and Belief. A New Sociology of Knowledge? In Sociological Review Monograph, Law J. (eds.). Routledge and Kegan Paul: London; 264-280.

Ledgerwood J, White V. 2006. Transforming microfinance institutions: providing full financial services to the poor. World Bank Publications.

Miles M, Huberman A.M. 1994. Qualitative data analysis: An expanded sourcebook. Second Edition. Thousand Oaks, CA: Sage.

Microfinance Information Exchange and Consultative Group to Assist the Poor. 2011. Eastern Europe and Central Asia Microfinance Analysis and Benchmarking Report 2010. Washington, DC.

Morduch J. 1999. The Role of Subsidies in Microfinance: evidence from The Grameen Bank. Journal of Development Economics 1999, 60 (1): 229-248.

National Statistical Service of the Republic of Armenia 2013. Social Snapshot and Poverty in Armenia.

Pache A, Santos F. 2010. When Worlds Collide: The Internal Dynamics of Organizational Responses to Conflicting Institutional Demands. Academy of Management Review 2010, 35 (3): 455-476. 
Pal D, Dutta O. 2015. Microcredit and Empowerment of Urban Women: A Study from Eastern India. Strategic Change 2015, 24: 149-163.

Pytkowska J, Rataj M. 2007. The State of Microfinance Industry in Eastern Europe and Central Asia 2006. Microfinance Centre.

Rippey P. 2009. Microfinance and climate change: Threats and opportunities. CGAP Focus Note 53. Washington, DC: CGAP.

Shipton P. 2010. Credit between cultures. Farmers, financiers and misunderstandings in Africa. New-Haven and London: Yale University Press.

Schuite G.J., Pater A. 2008. The triple bottom line for microfinance. Bunnik: Triodos Facet.

Tedeschi G.A. 2006. Here today, gone tomorrow: Can dynamic incentives make microfinance more flexible? Journal of Development Economics 2006, 80: 84- 105.

Van Elteren A. 2007. Environmental and social risk management and added value at MFIs and MFI funds: The FMO approach. The Hague: Netherlands Development Finance Company (FMO).

Varian H. 1990. Monitoring agents with other agents. Journal of Institutional and Theoretical Economics 1990, 146: 153-174.

World Bank. 2014. Development Indicators: Poverty rates at national poverty lines.

Xu S, Copestake J, Peng X. 2015. Microfinance institutions' mission drift in macroeconomic context. Journal of International Development 2015, DOI: 10.1002/jid.3097.

Yin R. 2003. Case Study Research. (2nd ed.). Thousand Oaks, CA: Sage Publishing. 